\title{
Effect of Sauropus androgynus Leaf Extract plus Turmeric Powder Supplementation on Broiler Performance
}

\author{
Urip Santoso ${ }^{1 *}$, Yosi Fenita ${ }^{1}$, Suharyanto ${ }^{1}$, Agus Martono Hadi Putranto ${ }^{2}$ \\ ${ }^{1}$ Department of Animal Science, Faculty of Agriculture, Bengkulu University \\ ${ }^{2}$ Department of Chemistry, Faculty of Mathetamics and Natural Science, Bengkulu University \\ Jalan Raya WR Supratman, Kandang Limun Bengkulu 38371A, Bengkulu, Indonesia \\ *Corresponding author: santoso@unib.ac.id
}

Artikel ini diterima (received): 15 November 2019; dinyatakan disetujui (accepted): 13 Januari 2020; terbit (published): 15 Mei 2020. Artikel ini dipublikasi secara daring pada https://ejournal.unib.ac.id/index.php/buletin_pt

\section{ABSTRACT}

A factorial design was used to evaluate the effect of Sauropus androgynus leaf extract (SALE) and turmeric powder (TP) on performance of broilers fed high-fat diet. Two dietary fat sources (6\% beef tallow or $6 \%$ palm oil), and five mixtures of SALE plus TP ( $0 \mathrm{~g}$ SALE plus $0 \mathrm{~g}$ TP, $9 \mathrm{~g}$ SALE plus $0.5 \mathrm{~g}$ TP, $18 \mathrm{~g}$ SALE plus $0.5 \mathrm{~g}$ TP, $9 \mathrm{~g}$ SALE plus $1 \mathrm{~g}$ TP, $18 \mathrm{~g}$ SALE plus $1 \mathrm{~g}$ TP) were studied. Experimental results showed that dietary fat sources, and SALE pulus TP mixture had no effect on body weight gain, feed intake and feed coversition ratio $(P>0.05)$. No interaction was found between two factors $(P>0.05)$. In conclusion, the addtion of SALE plus TP to high-fat diet did not improve broiler performance.

Key words: Sauropus androgynus, turmeric, performance

\section{INTRODUCTION}

Fats have an important role in the diet of broiler chickens. They functions as a source of energy and essential fatty acids, and these fats also increased diet palatability and fat-soluble vitamins absorption. Thus, feeding a high-fat diet may be useful in meeting the energy requirements of broiler chickens. In additon, feeding a high-fat diet improves growth efficiency because of enhanced feed efficiency (Breslin et al., 2010; Jeffri et al., 2010), and causes longer feed retention in the gastrointestinal tract; and improves nutritional digestion and absorption (Fouad and ElSenousey, 2014).

Sauropus androgynus leaf extract (Santoso, 2001; Santoso et al., 2002) and turmeric (Durrani et al., 2006) also improved growth performance in broiler. Therefore, the present study was conducted to evaluate effect of fat sources and Sauropus androgynus leaf extract plus turmeric powder on broiler performances.

\section{MATERIALS AND METHODS}

Sauropus andrognus leaf extraction: Sauropus androgynus leaf was extracted according to the method of Santoso et al. (2005), whereas turmeric powder was obtained from the traditional drug market. Basal diet contained $19 \%$ crude protein and 3,200 kcal $\mathrm{ME} / \mathrm{kg}$ diet.

Animals and diets: Two hundred broilers were purchased (Arbor Acres) from commercial hatcheries. The broilers used in this study were maintained according to Santoso et al. (2015). On arrival, the broilers were placed in a single pen surrounded with a bamboo ring and kept on rice husks at a depth of approximately $5 \mathrm{~cm}$. They were fed commercial starter diet for 20 days. At 21 days of age, the broilers were weighed and selected on the basis of body weight. One hundred and fifty broiler chickens aged 21 days were then distributed to ten treatment groups of 3 pens as replicates. Each pen contained 5 broiler chickens. The present experiment was arranged as completely randomized factorial design $(2 \times 5)$ in which two dietary fat sources (6\% beef tallow or $6 \%$ palm oil), and five mixtures of SALE plus TP ( $0 \mathrm{~g}$ SALE plus $0 \mathrm{~g}$ TP, $9 \mathrm{~g}$ SALE plus $0.5 \mathrm{~g}$ TP, $18 \mathrm{~g}$ SALE plus $0.5 \mathrm{~g}$ TP, $9 \mathrm{~g}$ SALE plus $1 \mathrm{~g}$ TP, $18 \mathrm{~g}$ SALE plus $1 \mathrm{~g}$ TP) were evaluated. Broilers were weighed weekly and feed intakes were recorded daily. 
Broilers were fed commercial starter diet for one day to 20 days of age. Thereafter, they were fed experimental diets (Table 1). Drinking water and diets were given ad libitum.

Data analysis: All data were subjected to analysis of variance as a $2 \times 5$ factorial arrangement of dietary treatments with dietary fat sources and SALE-TP mixture as main effects. Duncan's Multiple Range Test was used to determine which treatments were significantly different.

\section{RESULTS AND DISCUSSION}

Experimental results showed that dietary fat sources had no effect on body weight gain, feed intake and feed conversion ratio $(P>0.05) \quad$ (Table 1), whereas supplementation of SALE plus TP mixture did not affect those variables (Table 2). No interaction $(P>0.05)$ between two factors was found (Table 3 ).

The present study showed that the supplementation of SALE plus TP mixture did not improve growth performance of broiler chickens fed a high-fat diet. These results were different from Santoso (2001) and Santoso et al. (2002) who found that supplementation of SALE enhanced growth performance of those fed a normal-fat diet. Durrani et al. (2006) found that supplementation of $0.5 \%$ turmeric powder enhanced growth performance of broiler chickens. Lower supplementation of turmeric powder did not increase growth performance of broiler chickens (Mehala and Moorthy, 2008; Sinurat et al. 2009). Therefore, the level of turmeric powder applied in the present study should be increased to improve growth performance. Santoso et al. $\left(2015^{b}\right)$ also reported that supplementation of SALE plus TP to a low-protein diet did not improve broiler performance.

Feeding a beef-tallow diet resulted in similar performance quality to feeding a palmoil diet in the present study. This result was in contrary with Alao and Balnave (1985) who reported that unsaturated vegetable-oil diet produced lower faecal energy losses than animal-fat diet, and therefore, it improved growth performance. It has been established that beef-tallow and palm-oil had a relatively similar amount of unsaturated fatty acid (Chowdhury et al., 2007; Rezaei et al., 2013), and therefore, they caused similar quality of performance.

Table 1. Effect of dietary fat sources on performance of broiler chickens fed a high-fat diet

\begin{tabular}{lcccc}
\hline \multicolumn{1}{c}{ Variables } & $6 \%$ BT & $6 \%$ PO & SD & P \\
\hline $\begin{array}{l}\text { Body weight gain } \\
\text { (g/bird) }\end{array}$ & $1,062.8$ & 1,029 & 52.0 & $\mathrm{~ns}$ \\
$\begin{array}{l}\text { Feed intake } \\
\text { (g/bird) }\end{array}$ & 2,367 & 2,399 & 55.5 & $\mathrm{~ns}$ \\
Feed conversion & 2.21 & 2.33 & 0.13 & $\mathrm{~ns}$ \\
\hline
\end{tabular}

$\mathrm{BT}=$ beef tallow, $\mathrm{PO}=$ palm oil, $\mathrm{ns}=$ non significant.

Table 2. Effect of Sauropus androgynus leaf extract plus turmeric powder supplementation to a high fat diet on performance of broiler chickens

\begin{tabular}{|c|c|c|c|c|c|c|c|}
\hline Variables & P1 & $\mathrm{P} 2$ & P3 & P4 & P5 & SD & $P$ \\
\hline $\begin{array}{l}\text { Body weight gain } \\
\text { (g/bird) }\end{array}$ & $1,047.5$ & $1,072.8$ & $1,097.3$ & 964.7 & $1,047.2$ & 57.2 & Ns \\
\hline $\begin{array}{l}\text { Feed intake } \\
\text { (g/bird) }\end{array}$ & 2,335 & $2,350.3$ & $3,665.7$ & $2,322.3$ & $2,451.3$ & 79.8 & Ns \\
\hline Feed conversion & 2.26 & 2.20 & 2.16 & 2.44 & 2.37 & 0.17 & Ns \\
\hline
\end{tabular}




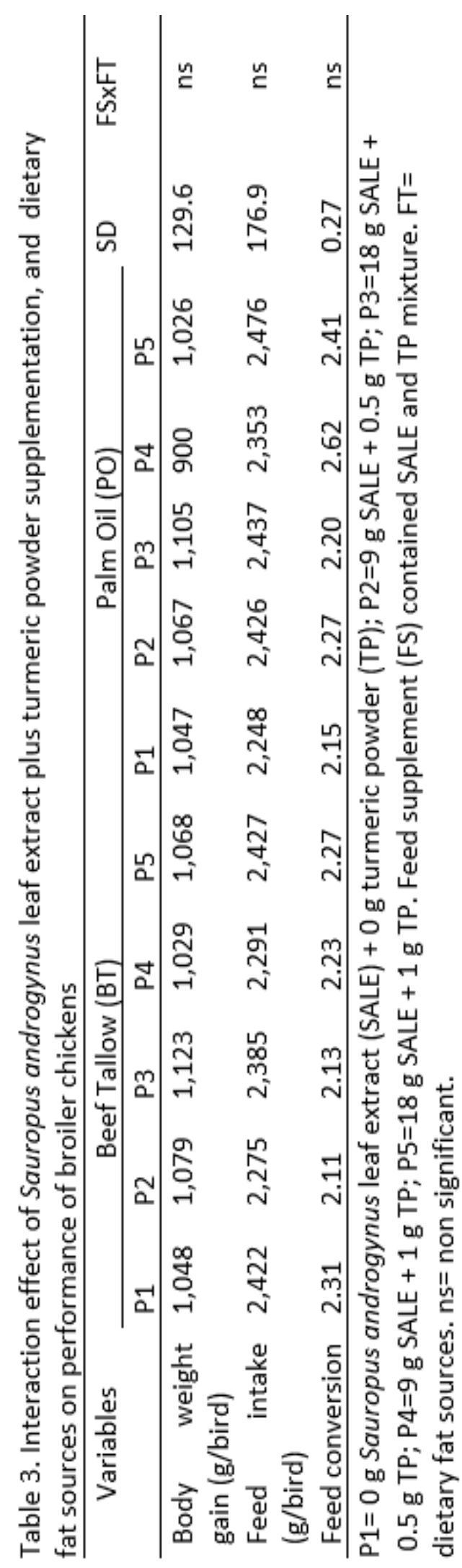

\section{CONCLUSION}

In conclusion, the addtion of SALE plus TP to high-fat diet did not improve broiler performance.

\section{ACKNOWLEDGMENTS}

The present experiment was supported by Directorate General of Higher Education,
Ministry of National Education under contract number: 2234/H30.10.06.01/HK/2010.

\section{REFERENCES}

Alao, S.J. and D. Balnave. 1985. Nutritional significance of different fat sources for growing broilers. Poultry Sci., 64:16021604.

Breslin, W.L., K. Strohacker, K.C. Carpenter, L. Esposito and B.K. McFarlin. 2010. Weight gain in response to high-fat feeding in CD-1 male mice. Lab. Anim., 44: 231-237.

Chowdhury, K., L.A. Banu, S. Khan and A. Latif. 2007. Studies on the fatty acid composition of edible oil. Bangladesh J. Sci. Ind. Res., 42: 311-316.

Durrani, F.R., M. Ismail, A. Sultan, S.M. Suhail, N. Chand and Z. Durrani. 2006. Effect of different levels of feed added turmeric (Curcuma longa) on the performance of broiler chicks. J. Agric. Biol. Sci., 1: 9-11.

Fouad, A.M. and H.K. El-Senousey. 2014. Nutritional factors affecting abdominal fat deposition in poultry: a review. Asian-Aust. J. Anim. Sci., 27: 1057-1068.

Jeffri, D., H. Firman and A. Kamyab. 2010. Comparison of soybean oil with an animal/vegetable blend at four energy levels in broiler rations from hatch to market. Int. Poultry Sci., 9:1027-1030.

Mehala, C. and M. Moorthy. 2008. Production performance of broilers fed with Aloe vera and Curcuma longa (turmeric). Int. J. Poultry Sci., 7: 852-856.

Rezaei, F., M. Gharachorloo and R. Azizinejad. 2013. Fractionation of iranian beef tallowchemical and physical evaluations of the fractions. JFBT IAU, 3: 37-40.

Santoso, U. 2001. Effect of Sauropus androgynus extract on the performance of broiler. Buletin Ilmu Peternakan dan Perikanan, 7: 15-21.

Santoso, U., T. Suteky, Heryanto and Sunarti. 2002. Pengaruh cara pemberian ekstrak daun katuk (Sauropus androgynus) terhadap penampilan dan kualitas karkas ayam pedaging. JITV 7: 144-149.

Santoso, U., J. Setianto and T. Suteky. 2005. Effects of Sauropus androgynus (katuk) extract on egg production and lipid metabolism in layers. Asian-Australasian J. Anim. Sci., 18: 364-369. 
Santoso, U., Y. Fenita and Kususiyah. 2015a Effect of fermented Sauropus androgynus leaves on meat composition, amino acid and fatty acid compositions in broiler chickens. Pak. J. Nutr., 14: 799-807.

Santoso, U., Kususiyah and Suharyanto, $2015^{\mathrm{b}}$. The effect of Sauropus androgynus leaves extract plus turmeric powder on fat deposition, carcass quality and blood profile in broilers fed low protein diets. J. Indonesian Trop. Anim. Agric., 40:121-130. Sinurat, A.P., T. Purwadaria, I.A.K. Bintang, P.P. Ketaren, M. Bermawie, M. Rahardjo and M. Rizal, 2009. The utilization of turmeric and Curcuma xanthorrhiza as feed additive for broilers. JITV, 14: 90-96. 